\title{
THE POTENTIAL USES OF SILYMARIN, A MILK THISTLE (Silybum Marianum) DERIVATIVE, IN POULTRY PRODUCTION SYSTEM
}

\author{
Wafaa A. ABD EL-GHANY $\approx$ \\ Poultry Diseases Department, Faculty of Veterinary Medicine, Cairo University, Giza, Egypt \\ ${ }^{\otimes}$ Email: wafaa.ghany@yahoo.com; (D) ORCiD: 0000-0003-1686-3831 \\ supporting Information
}

\begin{abstract}
Due to recent intensive poultry production, there is a great demand to use natural alternative feed additives. One of these alternatives is phytobiotics. Milk thistle (Silybum marianum) is a plant that has been used for many years as a natural remedy for the liver diseases. Silymarin is the major dried extract of milk thistle. Silymarin has many flavonolignans that showed antioxidant, anti-inflammatory, anti-fibrotic, antilipid peroxidative, immune stimulant, and hepatic cells stabilizing effects. In poultry production system, silymarin has been used in broilers as a growth promotor and in layers to improve the egg quantity and quality. It has been also used as a hepatotonic substance as a result of a potent antioxidant activity. The carcass trait showed improvement after treatment of broilers with silymarin. In addition, enhancement of the immune system and the intestinal health has been detected after application of silymarin in poultry diets. Accordingly, this review article aims to show the different potential uses of silymarin in poultry production system regarding its effect on production performance, antioxidant status, carcass traits, immune response, and intestinal health.
\end{abstract}

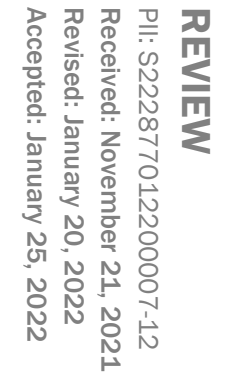

Keywords: Antioxidant, Carcass trait, Immunity, Intestinal health, S. marianum

\section{INTRODUCTION}

As a result of COVID-19 crisis and drastic decrease in the feed supply, search for alternative feed supplies becomes very urgent (Hafez and Attia, 2020). Moreover, it is important to decrease the need to include antibiotics in the nutrition of poultry to avoid the adverse effects of resistance and the harmful residues in poultry products (Castillo-Lopez et al., 2017). Addition of phytobiotics to poultry feed is regarded as an effective alternative approach. Phytobiotics can improve the nutrient digestibility and the function of birds via increasing the secretion of digestive enzymes and the number of natural flora, reducing the viscosity of digestive substances, enhancing the immune system, and lowering the blood cholesterol level (Ritz et al., 1995).

Milk thistle plant or Silybum marianum L. Gaernt. (S. marianum), sometimes called wild artichoke, is a member of Asteraceae family (Pepping, 1999). It has been previously used in medicine as a natural remedy for the liver and biliary tract (Morazzoni and Bombardelli, 1995). The dried extracts of S. marianum seeds contain approximately $60 \%$ silymarin (Bhattacharya, 2011). It is the active ingredient of milk thistle, which represents $4 \%$ of the dried seeds or in the aerial parts of the plant (Rajiha, 2012). It can be used as a non-toxic, safe, and cheap liver tonic feed additive to substitute synthetic drugs in poultry diets (Saeed et al., 2017). Silymarin was initially found in the Mediterranean mountain, North Africa, and Asia, but today, it has been grown in many parts world-wide (Khan et al., 2009).

Silymarin contains many flavonolignans such as silybin (50\%-60\%), silychristin (20\%), silydianin (10\%), and isosilibine (5\%) as well as flavonoid (taxifolin) (Federico et al., 2017; Attia et al., 2019). Silymarin complex showed antioxidant, antiinflammatory, anti-fibrotic, anti-lipid peroxidative, immune stimulant, and hepatic cells stabilizing effects (Suchy et al., 2008; Saeed et al., 2017). Furthermore, milk thistle seeds contain betaine, trimethyl glycine, and essential fatty acids which involved in the hepatoprotective and anti-inflammatory actions of the silymarin complex (Saller et al., 2001).

The different beneficial effects of silymarin have been previously reported in poultry production. It is considered as a potential feed additive to broilers in terms of enhancement of the growth performance, prevention of oxidative stress, improvement of the meat quality, increasing the production of polyunsaturated fatty acids, and stimulation of immune status (Zaker-Esteghamati et al., 2020; Bagno et al., 2021; Armanini et al., 2021).

Based on abovementioned findings, this review article aims to show the different potential uses of milk thistle derivative, silymarin, in poultry production system regarding its effect on production performance, antioxidant status, carcass traits, immune response, and intestinal health. 


\section{THE DIFFERENT EFFECTS OF SILYMARIN IN POULTRY PRODUCTION SYSTEM}

\section{Production performance}

Researchers showed that silymarin can improve the productive and reproductive performances and the health status of chickens (Abdulwahid and Oleiwi, 2021; Armanini et al., 2021), ducks (Egresi et al., 2020), and quails (Soto et al., 2003; Behboodi et al., 2017; Khaleghipour et al., 2019, 2020). Treatment of turkeys with silymarin at doses of $0.5 \mathrm{~kg}$ and $1 \mathrm{~kg}$ / ton of feed mixture induced higher live body weight compared with un-treated control group (Gawel et al., 2003). Zarei et al. (2016) inoculated $1 \mathrm{ml}$ of two dilutions (100 and $200 \mathrm{mg} / \mathrm{L}$ ) of milk thistle extract in ovo and then added it to the feed mixture at a dose of $100 \mathrm{mg} / \mathrm{kg}$. The results indicated higher final live weight of chickens compared to the control group. Besides, Abdalla et al. (2018) found an improvement in the body weight of chickens supplemented with silymarin ( $25 \mathrm{~g} / \mathrm{kg}$ of diet) under the Egyptian summer conditions. Broiler chickens consumed silymarin (160 mg/kg diet) at the starter, grower, and finisher stages of rearing showed improvement of the body weight gain and feed conversion indices (Mousa and Osman, 2016). In the study of Shahsavan et al. (2021), dietary inclusion of 3\%, 9\%, and $12 \%$ of S. marianum oil extraction byproduct into the diet of broilers induced an increase in the body weight, feed intake, and the feed conversion rate. Various concentrations of silymarin $(0,100$, and $200 \mathrm{mg} / \mathrm{kg})$ in broilers enhanced the growth performance after exposure to lead-induced oxidative stress (Ebrahimi et al., 2013). In addition, it can alleviate the toxic effects of mycotoxins and improve the impairment of growth performance parameters elicited by mycotoxins in broilers (Kalorey et al., 2005; Chand et al., 2011; Surai, 2015; Morovat et al., 2016; Alhidary et al., 2017). Improved feed intake and feed conversion rate were observed in broiler chicks fed on a diet containing $0.8 \mathrm{mg} / \mathrm{kg}$ aflatoxin and treated with $600 \mathrm{mg} / \mathrm{kg}$ silymarin (Tedesco et al., 2004). Muhammad et al. (2012) reported that silymarin at a level of $10 \mathrm{~g} / \mathrm{kg}$ diet increased the feed intake and the weight gain of broilers fed on rations contaminated with aflatoxin. In the same line, dietary supplementation with silymarin ameliorated the decreased feed intake and the body weight gain and improved the feed conversion rate of aflatoxin-challenged broiler chicks (Jahanian et al., 2017). A concentration of silymarin (500 $\mathrm{g} /$ ton feed) was able to mitigate the negative effect of aflatoxins on the metabolism and growth performance of laying Japanese quails (Sakamoto et al., 2018). Silymarin supplementation of aflatoxicated chicks increased the body weight gain as the result of increasing the feed intake and the protein synthesis in the hepatic cells (Sonnebichler and Zetl, 1986) as well as enhancing the digestibility and absorption of nutrients by increasing the digestive enzymes (Sultan et al., 2018). Moreover, enhanced growth performance parameters in silymarin-treated birds may be owing to the hepatoprotective and the detoxifying activities of S. marianum against mycotoxins (Baer-Dubowska et al., 1998; Fraschini et al., 2002). This compound can reduce the intestinal ulcer index and increased the mucin content (Huilgol and Jamadar, 2013).

\section{Antioxidant}

Silymarin restored the oxidant and antioxidant activities to the normal physiological conditions that benefit animal health and consequently human consumers (Armanini et al., 2021). This compound restored all changes in liver and serum after intoxication with aflatoxin and that indicates its hepatotonic effect (Rastogi et al., 2000). Addition of $800 \mathrm{mg}$ silymarin/ $\mathrm{kg}$ feed to a diet of broilers containing $1 \mathrm{mg} / \mathrm{kg}$ aflatoxin inhibited the increase in alanine aminotransferase (ALT) activity (Jamshidi et al., 2007). Similar result was also reported by Tedesco et al. (2004) and Fani Makki et al. (2014). A recent study of Tsiouris et al. (2021) indicated that dietary supplementation of broiler diet with detoxifying agent containing modified zeolite, Bacillus (B.) subtilis, B. licheniformis, Saccharomyces cerevisiae cell walls, and silymarin ameliorated the adverse effects aflatoxin and ochratoxin. In ducks, a concentration of $0.5 \%$ silymarin decreased the oxidative stress of the liver after feeding on diets containing zearalenone and deoxynivalenol (Egresi et al., 2020). In other avian species such as Japanese quails, silymarin reduced the concentration of triglyceride and cholesterol when compared with carbon tetrachloride treated group (Behboodi et al., 2017; Moradi et al., 2017). Silybin, the major active constituent of silymarin, has antioxidant characters, hepatoprotective effect, and free radical scavenging activities (Fraschini et al., 2002; MacDonald-Ramos et al., 2021). This antioxidant effect may achieved by reservation of the hepatocytes membranes integrity, stabilization of phospholipid structure, activation of nucleic acids and protein biosynthesis, and stimulation of immunity (Vargas-Mendoza et al., 2014; Saeed et al., 2017). Silymarin decreased the secretion of some hepatic enzymes such as ALT, aspartate aminotransferase (AST), and alkaline phosphatase into blood as a result of hepatic injuries from free radicals (Amiridumari et al., 2013; Armanini et al., 2021) and also reduced the oxidation of lipid and protein (Alhidary et al., 2017) and the apoptosis of DNA (Upadhyay et al., 2010). Moreover, it has been found that silymarin prevented lipid peroxidation and returned some antioxidant enzymes such as catalase, superoxide dismutase, and glutathione peroxidase in the hepatic cells of chickens after ochratoxin damaging effects (Yu et al., 2018; Armanini et al., 2021). This compound also returned some other antioxidants vitamins such as vitamins $E$ and vitamin $C$ in the liver (Pradeep et al., 2007). In a quail's trial, the results indicated that silymarin decreased the levels of bilirubin, malondialdehyde (MDA), ALT, triglyceride, and cholesterol, while increased the levels of albumin, protein total, superoxide dismtase, total antioxidant, and glutathione peroxidase (Moradi et al., 2017). Alassi and Allaw (2020) found that addition $1 \mathrm{~g} / \mathrm{kg}$ milk thistle seed powder in quail's diet lowered the level of cholesterol, glutathione, MDA, ALT, and AST. Silymarin reduced the biliary cholesterol and phospholipids which may be in part due to decreased liver cholesterol synthesis (Crocenzi and Roma, 2006; Bhattachrya, 2011). Silymarin may be able to mitigate the oxidative stress-induced 
by carbon tetrachloride in broilers through modulation of oxidative stress biomarkers and hepatic oxidative genes expression (Baradaran et al., 2019).

Bhattachrya (2011) found that silymarin may maintain the normal renal function and silibinin can reduce the oxidative damage to kidney cells in vitro. In the same line, silymarin $(259 \mu \mathrm{M})$ affected heat shock protein expression and prevented its alleviation by heat stress on chicken lymphocytes cells (Oskoueian et al., 2014). The previous study also showed that silymarin was able to normalize the expression of biomarkers such as MDA, tumor necrotizing factor-like, interferon (IFN- $\mathrm{\gamma}$ ), and interleukin (IL-1 $\beta$ ) genes in heat-induced chicken hepatocytes. Moreover, the study of Ledur and Santurio (2020) indicated that the in vitro addition of $5 \mu \mathrm{M}$ silymarin to PK-15 cells exposed to different mycotoxins reduced the reactive oxygen species formation.

Silymarin may exert the hypoglycaemic effect through increasing the secretion of insulin via beta cells of the pancreas, enhancing the renovation of pancreatic cells, and protection of the pancreatic tissues against some metabolic damage (Soto et al., 2004; Kshirsagar et al., 2013). In addition, silymarin could regulate the liver enzymes involved in metabolism of carbohydrates causing reduction in the blood glucose level and restoring weights. This occurs due to decrease the activity of liver phosphorylase activity and increase glucokinase and glycogen synthase (Abascal and Yarnell, 2003).

\section{Carcass traits}

The highest breast weight muscle was detected in broilers received $1 \%$ of silymarin, compared with the groups consumed the different levels of aflatoxin (Chand et al., 2011). Addition of both L-carnitine and silymarin at levels of 300 $\mathrm{mg}$ and $160 \mathrm{mg} / \mathrm{kg}$ diet, respectively reduced the abdominal fat deposition and increased the weight of thigh muscles of broiler chickens in comparison with the control group (Mousa and Osman, 2016). Zaker-Esteghamati et al. (2020) concluded that dietary addition of $4-15 \%$ silymarin improved the sensory and qualitative properties of broilers meat after exposure to aflatoxin diet. The authors found that the highest carcass weight and breast weight were detected in chickens fed on $3 \%$ silymarin oil. The improvement of carcass yield of silymarin-supplemented broilers may be related to the increase in protein synthesis (Sonnebichler and Zetl, 1986; Gawel et al., 2003; Jahanian et al., 2017). It has been found that silymarin has a similar structure to the steroid hormones, accordingly, it can pass to the nucleus and improve the formation of ribosomes via increasing the synthesis of structural and functional proteins by acting on rRNA enzymes (Negahdary et al., 2015).

It can enhance the meat polyunsaturated fatty acid profile which impaired by mycotoxin (Armanini et al., 2021). Schiavone et al. (2007) found that silymarin decreased the lipid contents of the thigh and breast muscles of broilers and increased the muscle resistance to oxidative stress. Changes in fatty acids metabolism at the hepatic level is owing to the hepatotonic effect of this compound (Saeed et al., 2017).

\section{Immune response}

Regulation of the immune system induced by silymarin depends on the method used and its concentration (Gharagozloo et al., 2010). Improvement of the immune status after feeding on milk thistle fruits was reported (Thyagarajan et al., 2002; Khariv et al., 2017; Alassi and Allaw, 2020; Bagno et al., 2021). Early study of Basaga et al. (1997) showed that milk thistle could enhance the immune system via its powerful antioxidant and free radical scavenging action. Long term administration of silymarin could improve the immune response by increasing the production of T-lymphocytes and IL and also it could be useful as a therapeutic adjuvant for autoimmune and infectious diseases (Das et al., 2008). Saeed et al. (2017) demonstrated that silymarin can modulate the immune response of birds by increasing the levels of IL-4, IL-10, and IFN-y. Some studies indicated that the use of silymarin under oxidative stress of carbon tetrachloride can have a positive effect on the humoral immunity of Japanese quail via increasing in the concentrations of immunoglobulin G, the total antibodies, and white blood cell count (Moradi et al., 2017). Vitamin E and silymarin alone or in combination improved the immunotoxic effects induced by ochratoxin in Leghorn cockerels (Khatoon et al., 2013). Silymarin, as antioxidant, has protective action against the oxidative damages on the immune organs such as bursa of Fabricious, thymus, and spleen (Chand et al., 2011). This product decreased the relative weights of bursa of Fabricious and spleen, while increased the relative weight of the thymus (Moradi et al., 2017). Similarly, S. marianum was efficient in protection of spleen and bursa of Fabricious against the adverse effects of aflatoxin (Kalorey et al., 2005; Fani Makki et al., 2013). Chickens fed by diets containing $9 \%$ of S. marianum oil extraction byproduct showed greater spleen weights compared to chickens fed concentrations of 3\%, 6\%, and $12 \%$ (Shahsavan et al., 2021). A recent study of Bagno et al. (2021) showed increasing the content of $\mathrm{y}$-globulins in the serum of chickens fed on various doses of milk thistle extract $(0.1,0.5,1.0,1.5$, and $2.0 \mathrm{mg} / \mathrm{kg}$ of body weight) as compared to the control group. Dumari et al. (2014) demonstrated that the serum antibody titers against Newcastle and influenza diseases viruses were higher than those recorded in aflatoxin treated group. Lutensko et al. (2008) found that silymarin phytosome increased albumin and globulin levels when compared with aflatoxicated broiler chickens. The cutaneous basophilic hypersensitivity response to phytohemagglutinin-P injection indicated that chickens received $9 \%$ of $S$. marianum oil extraction byproduct recorded high wing web thickness at $24 \mathrm{~h}$ following injection (Shahsavan et al., 2021). Denev et al. (2020) demonstrated an increase in the level of serum betalysine after ditary addition of silymarin to ochratoxin challenged broiler chickens. 


\title{
Intestinal health
}

Treatment of Japanese quails with $1 \mathrm{ml} / \mathrm{kg}$ body weight silymarin increased the length of villi and the ratio of villi length to crypt depth (Moradi et al., 2017). Dietary supplementation of aflatoxicated broilers with 500 ppm silymarin increased the villi height and width, the ratio between villi height and crypt depth, and the apparent villi absorptive area (Jahanian et al., 2017). Accordingly, this product can protect the villi from endotoxins produced by pathogenic bacteria. Shahsavan et al. (2021) found an increase in the duodenum, jejunum, and cecum of broilers fed on S. marianum oil extraction byproduct at the levels of $6 \%, 9 \%$, and $12 \%$ compared to control.

Both Gram-positive and Gram-negative bacteria can be affected by silymarin and silibinin (Lahlah et al., 2012). In other study, caecal population of Lactobacillus, coliform, Escherichia coli (E. coli), total aerobes, and Lactobacilli/E. coli ratio were not influenced by the treatments by S. marianum oil extraction byproduct (Shahsavan et al., 2021). Under the in-vitro conditions, S. marianum showed antibacterial activities against Staphylococcus saprophyticus, E. coli, and Klebsiella pneumonia (Evren and Yurtcu, 2015). Generally, silymarin exerts its antibacterial effect through hydroxyl group which binds with the bacterial membrane proteins leading to the leakage of vital components of the cells (Lee et al., 2003; Bessam and Mehdadi, 2014).

\section{CONCLUSION}

Application of natural alternative to antibiotics in poultry production system is urgently needed. Phytobiotics gained a great acceptance as one of these alternatives. Silymarin, a derivative of milk thistle herb, is widely used as a potent hepatotonic and antioxidant natural feed additive. Silymarin has a potential to increase the production performance in broilers and layers, increase the antioxidant status, improve the carcass trait, stimulate the immune response, and enhance the intestinal health. Thus, it is recommended to use such compound as feed additive in poultry field.

\section{DECLARATIONS}

\author{
Corresponding author \\ E-mail: wafaa.ghany@yahoo.com
}

\begin{abstract}
Author's contribution
Abd El-Ghany WA has collected and drafted the manuscript, formatted it, and approved the final manuscript.
\end{abstract}

\section{Conflict of interests}

The author has not declared any conflict of interest.

\section{REFERENCES}

Abascal K, and Yarnell E (2003). The many faces of Silybum marianum (milk thistle): Part 1 - Treating cancer and hyperlipidemia and restoring kidney function. Alternative and Complementary Therapies, 9(4): 170-175. DOI: https://doi.org/10.1089/107628003322256878

Abdalla AA, Abou-Shehema BM, Rawia SH, and Elden MR (2018). Effect of silymarin supplementation on the performance of developed chickens under summer conditions 1-during growth period. Egyptian Poultry Science Journal, 38(1): 305-329. D0I: https://dx.doi.org/10.21608/epsj.2018.5667

Abdulwahid MT, and Oleiwi AF (2021). Ameliorating effects of silymarin against mycotoxin and its effect on some production and hematological parameters of broilers. Journal of Genetic and Environmental Resources Conservation, 9(1): $207-214$. https://gercj.com/index.php/gercj/article/view/105/77

Alassi SB, and Allaw AA (2020). Effect of adding of the milk thistle (Silybum marianum) seed powder in the traits of biochemical blood of the quail. Plant Archives, 20(1): 962-964. http://www.plantarchives.org/20-1/962-964\%20(5677).pdf

Alhidary I, Rehman Z, Khan R, and Tahir M (2017). Anti-aflatoxin activities of milk thistle (Silybum marianum) in broiler. World's Poultry Science Journal, 73(3): 559-566. DOI: https://doi.org/10.1017/S0043933917000514

Amiridumari H, Sarir H, Afzali N, and Fanimakki O (2013). Effects of milk thistle seed against aflatoxin B1 in broiler model. Journal of Research in Medical Sciences, 18(9): 786-790. https://www.ncbi.nlm.nih.gov/pubmed/24381623

Armanini EH, Boiago MM, Cécere BGO, Oliveira PV, Teixeira CJS, Strapazzon JV, Bottari NB, Silva AD, Fracasso M, Vendruscolo RG, Wagner R, Gloria EMD, Horn VW, Mendes RE, Baldissera MD, Vedovatto M, and Da Silva AS (2021). Protective effects of silymarin in broiler feed contaminated by mycotoxins: growth performance, meat antioxidant status, and fatty acid profiles. Tropical Animal Health and Production, 53(4): 442. DOI: https://doi.org/10.1007/s11250-021-02873-2

Attia YA, Hamed RS, Bovera F, Al-Harthi MA, Abd El-Hamid AEHE, Esposito L, and Shahba HA (2019). Milk thistle seeds and rosemary leaves as rabbit growth promoters. Animal Science Papers and Reports, 37(3): 277-279. https://agro.icm.edu.pl/agro/element/bwmeta1.element.agro-bc2f7975-5dda-49eb-a05e-f7f4d5a18bc0?q=bwmeta1.element.agroc5647f4d-18ed-4206-9ede-

Baer-Dubowska W, Szaefer H, and DrajkaKuzniak V (1998). Inhibition of murine hepatic cytochrome P450 activities by natural and synthetic phenolic compounds. Xenobiotica, 28(8):735-743. DOI: https://doi.org/10.1080/004982598239155 
Bagno 0, Shevchenko S, Shevchenko A, Prokhorov O, Shentseva A, Vavin G, and Ulrich E (2021). Physiological status of broiler chickens with diets supplemented with milk thistle extract, Veterinary World, 14(5): 1319-1323. DOI: https://doi.org/10.14202/vetworld.2021.1319-1323

Baradaran A, Samadi F, Ramezanpour SS, and Yousefdoust S (2019). Hepatoprotective effects of silymarin on CCl4-induced hepatic damage in broiler chickens model. Toxicology Reports, 6: 788-794. DOI: https://dx.doi.org/10.1016\%2Fj.toxrep.2019.07.011

Basaga H, Poli G, Tekkaya C, and Aras I (1997). Free radical scavenging and antioxidative properties of 'silibin' complexes on microsomal lipid peroxidation. Cell Biochemistry and Function, 1: 27-33. DOI: https://doi.org/10.1002/(sici)1099-0844(199703)15:1\%3C27::aidcbf714\%3E3.0.co;2-w

Bessam FH, and Mehdadi Z (2014). Evaluation of the antibacterial and antifongigal activity of different extract of flavonoiques Silybum marianum L. Advances in Environmental Biology, 8(17): 1-9. http://www.aensiweb.net/AENSIWEB/aeb/aeb/September\%202014/19.pdf

Behboodi H, Samadi F, Shams Shargh M, Gangi F, and Samadi S (2017). Effects of silymarin on growth performance, internal organs and some blood parameters in Japanese quail subjected to oxidative stress induced by carbon tetrachloride. Poultry Science Journal, 5(1): 31-40. DOI: https://dx.doi.org/10.22069/psj.2017.11578.1201

Bhattacharya S (2011). Milk thistle (Silybum marianum L. Gaert.) seeds in health. In: Preedy VR, Watson RR, Patel V. Editors. Nuts and Seeds in Health and Disease Prevention. 1st Ed., London, Burlington, San Diego: Academic Press. https://doi.org/10.1016/B978-012-375688-6.10090-8

Castillo-Lopez RI, Gutierrez-Grijalva EP, and LeyvaLopez N (2017). Natural alternatives to growth-promoting antibiotics (GPA) in animal production. Journal of Animal and Plant Science, 27(2): 349-359. http://www.thejaps.org.pk/.../01.php

Chand N, Muhammad D, Durrani FR, Qureshi S, and Ullah SS (2011). Protective effects of milk thistle (Silybum marianum) against aflatoxin B1 in broiler chicks. Asian-Australian Journal of Animal Sciences, 24(7):1011-1018. https://doi.org/10.5713/ajas.2011.10418

Crocenzi FA, and Roma MG (2006). Silymarin as a new hepatoprotective agent in experimental cholestasis: new possibilities for an ancient medication. Current Medicinal Chemistry, 13(9): 1055-1074. DOI: https://doi.org/10.2174/092986706776360950

Das SK, Mukherjee S, and Vasudevan DM (2008). Medicinal properties of milk thistle with special reference to silymarin: An overview. Natural Product Radiance, 7(2): 182-192. http://hdl.handle.net/123456789/5665

Denev S, Sotirov L, Chobanova S, Koynarski T, Ivanov V, Bozakova N, and Stoev S (2020). Effect of silymarin and ochratoxin A on humoral natural immunity of broiler chickens. Journal of Central European Agriculture, 21(3): 492-498. Dol: https://doi.org/10.5513/JCEA01/21.3.2775

Dumari MA, Sarir H, Fani Makki O, and Afzal N (2014). Effect of milk thistle (Silybum marianum L.) on biochemical parameters and immunity of broiler chicks fed aflatoxin B1 after three weeks. Iranian Journal of Toxicology, 8(26): 1098-1103. http://ijt.arakmu.ac.ir/browse.php?a_code=A-10-2-170\&slc_lang=en\&sid=1

Ebrahimi R, Mahmmadabadi T, Sari M, Sallari S, Zamiri MJ, and Beygi Nasiri MT (2013). Effect of silymarin on lead-induced oxidative stress in broilers. Iranian Journal of Animal Science Research, 5(4): 302-312. https://www.sid.ir/en/Journal/ViewPaper.aspx?ID=432380

Egresi A, Sule K, Szentmihalyi, Blázovics A, Fehér E, Hagymási K, and Fébel H (2020). Impact of milk thistle (Silybum marianum) on the mycotoxin caused redox-homeostasis imbalance of ducks liver. Toxicon, 187:181-187. D0I: https://doi.org/10.1016/i.toxicon.2020.09.002

Evren E, and Yurtcu E (2015). In vitro effects on biofilm viability and antibacterial and antiadherent activities of silymarin. Folia Microbiologica, 60(4): 351-356. DOI: https://doi.org/10.1007/s12223-015-0399-6

Fani Makki O, Omidi A, Afzali N, Sarir H, Frouzanmehr M, and Shibak A (2014). Efficacy of Silybum marianum seeds in ameliorating the toxic effects of aflatoxin B1 in broilers. Iranian Journal of Toxicology, 8(24): 977-982. http://ijt.arakmu.ac.ir/browse.php?a id=293\&sid=1\&slc lang=en

Federico A, Dallio M, and Loguercio C (2017). Silymarin/silybin and chronic liver disease: a marriage of many years. Molecules, $22(2)$ : 191. DOI: https://doi.org/10.3390/molecules22020191

Fraschini F, Demartini G and Esposti D (2002). Pharmacology of silymarin. Clinical Drug Investigation, 22: 51-65. D0I: https://doi.org/10.2165/00044011-200222010-00007

Gawel A, Kotonski B, Madej JA, and Mazurkiewicz M (2003). Effect of silimarin on chicken and turkey broilers' rearing and the production indices of reproduction hen flocks. Medycyna https://eurekamag.com/research/034/804/034804936.php

Gharagozloo M, Velardi E, Bruscoli S, Agostini M, Di Sante M, Donato V, Amirghofran Z, and Riccardi C (2010). Silymarin suppress CD4+ T cell activation and proliferation: Effects on NF-KB activity and IL-2 production. Pharmacological Research, 61(5): 405-409. D0I: https://doi.org/10.1016/j.phrs.2009.12.017

Hafez MH, and Attia YA (2020): Challenges to the poultry industry: Current perspectives and strategic future after the COVID-19 outbreak. Frontiers in Veterinary Sciences, 7: 516. DOI: https://dx.doi.org/10.3389\%2Ffvets.2020.00516

Huilgol SV, and Jamadar MG (2013). Gastroprotective role of bioflavonoid silymarin in animal model of acute cold restraint stress induced gastric ulceration. Al Ameen Journal of Medicine Sciences, 6(1): 40-43. DOI: http://ajms.alameenmedical.org/ArticlePDFs/AJMS\%20V6.N1.2013\%20p\%2040-43.pdf

Jahanian E, Mahdavi AH, Asgary S, and Jahanian R (2017). Effects of dietary inclusion of silymarin on performance, intestinal morphology and ileal bacterial count in aflatoxin-challenged broiler chicks. Journal of Animal Physiology and Animal Nutrition, 101(5): e43-e54. DOI: https://doi.org/10.1111/jpn.12556

Jamshidi A, Ahmadi-Ashtiani H, Gholamhouseyni B, and Bokaei S (2007). Study on effects of oral administrating of Silybum marianum (L.) Gaertn. extract (silymarin) on biochemical factors and tissue changes caused by aflatoxin in broiler chickens. Journal of Medicinal Plants, 6(24): 92-100. http://jmp.ir/article-1-574-en.htm

Kalorey DR, kurkure NV, Ramgaonkar IS, Sakhare PS, Warke S, and Nigot NK (2005). Effect of polyherbal feed supplement "Growell" during induced aflatoxicosis, ochratoxicosis and combined mycotoxicoses in broilers. Asian-Australian Journal of Animal Science, 18(3): 375383. DOI: https://doi.org/10.5713/ajas.2005.375

Khaleghipour B, Khosravinia H, Toghiyani M, and Azarfar A (2019). Effects of silymarin on productive performance, liver function and serum biochemical profile in broiler Japanese quail challenged with dietary aflatoxins. Italian Journal of Animal Science, 18(1): 564-573. DOI: https://doi.org/10.1080/1828051X.2018.1548310 
Khaleghipour B, Khosravinia H, Toghiyani M, and Azarfar A (2020). Efficacy of silymarin-nanohydrogle complex in attenuation of aflatoxins toxicity in Japanese quails. Italian Journal of Animal Science, 19(1): 351-359. DOI: https://doi.org/10.1080/1828051X.2020.1743782

Khan MA, Blackshaw RE, and Marwat KB (2009). Biology of milk thistle (Silybum marianum) and the management options for growers in north-western Pakistan. Weed Biology and Management, 9: 99-105. DOI: https://doi.org/10.1111/i.1445-6664.2009.00326.x

Khariv I, Gutyj B, Hunchak V, Slobodyuk N, Vynyarska A, Sobolta A, Todoriuk V, and Seniv R (2017). The influence of brovitatoxide in conjunction with milk thistle fruits on the immune system of turkeys for eimeriozic invasion. Scientific Messenger of LNU of Veterinary Medicine and Biotechnologies. Series: Veterinary Sciences, 19(73): 163-168. DOI: https://doi.org/10.15421/nvlvet7334

Khatoon A, Khan MZ, Khan A, Saleemi MK, and Javed I (2013). Amelioration of ochratoxin A-induced immunotoxic effects by silymarin and vitamin $E$ in White Leghorn cockerels. Journal of Immunotoxicology, 10(1): 25-31. DOI https://doi.org/10.3109/1547691x.2012.686533

Kshirsagar M, Mahash V, Srinivas P, and Mangala L (2013). Evaluation of the protective effect of silymarin on doxorubicin induced chronic testicular toxicity in rats. International Journal of Pharma and Bio Sciences, 4(1): 473-484. https://ijpbs.net/abstract.php?article $=M j \mathrm{AzNw}==$

Lahlah ZF, Meziani M, and Maza A (2012). Silymarin natural antimicrobial agent extracted from Silybum marianum. Journal Academica, 2(3): 164-169. https://www.journalacademica.org/Vol2_4JA2012/Lahlah_164-169(2)4.pdf

Ledur PC, and Santurio JM (2020). Cytoprotective effects of curcumin and silymarin on PK-15 cells exposed to ochratoxin A, fumonisin B1 and deoxynivalenol. Toxicon, 185: 97-103. DOI: https://doi.org/10.1016/j.toxicon.2020.06.025

Lee DG, Kim HK, Park Y, Park SC, Woo ER, Jeong HG, and Hahm KS (2003). Gram positive bacteria specific properties of silybin derived from Silybum marianum. Archives of Pharmacal Research, 26: 597-600. DOI: https://doi.org/10.1007/BF02976707

Lutsenko S, Kashnikova T, Khmyrov A, Ledeshkova O, Fel'dman N, Luzhnov N, and Lutsenko EV (2008). Study of the effect of a liposomal form of silymarin on biochemical indices of the blood serum and productivity of broiler chicks. Russian Agricultural Sciences, 34(6): 415-417. DOI: https://doi.org/10.3103/S1068367408060165

MacDonald-Ramos K, Michán L, Martínez-lbarra A, and Cerbón M (2021). Silymarin is an ally against insulin resistance: A review. Annals of Hepatology, 23: 100255. DOI: https://doi.org/10.1016/j.aohep.2020.08.072

Moradi F, Samadi F, Dastar B, and Samadi S (2017). The effects of silymarin on oxidative status and bone characteristics in Japanese quail subjected to oxidative stress induced by carbon tetrachloride. Poultry Science Journal, 5(2): 97-104. DOI: https://dx.doi.org/10.22069/psj.2017.11432.1194

Morazzoni P, and Bombardelli E (1995). Silybum marianum (Carduus marianus). Fitoterapia, 66(1): 3-42. https://eurekamag.com/research/002/695/002695286.php

Morovat M, Chamani M, Zarei A, and Sadeghi AA (2016). Dietary but not in ovo feeding of Silybum marianum extract resulted in an improvement in performance, immunity and carcass characteristics and decreased the adverse effects of high temperatures in broilers. British Poultry Science, 57(1): 105-113. DOI: https://doi.org/10.1080/00071668.2015.1121537

Mousa MA, and Osman AS (2016). The implications of l-carnitine and silymarin supplementation on growth performance and some blood parameters of broilers. Assiut Veterinary Medical Journal, 62(148): 132-138. http://www.aun.edu.eg/iournal files/468 J 4913.pdf

Muhammad D, Chand N, Khan S, Sultan A, and Mushtaq M (2012). Hepatoprotective role of milk thistle (Silybum marianum) in meat type chicken fed aflatoxin B1 contaminated feed. Pakistan Veterinary Journal 32: 443-446. http://www.pvj.com.pk/pdf-files/32_3/443446.pdf

Negahdary M, Bezhgi M, and Ajdary M (2015). Effects of silymarin on oxidative stress markers in rats treated with magnesium oxide nanoparticles. Annual Research \& Review in Biology, 5(3): 254-261. DOI: https://doi.org/10.9734/ARRB/2015/10949

Oskoueian E, Abdullah N, Idrus Z, Ebrahimi M, Goh YM, Shakeri M, and Oskoueian A (2014). Palm kernel cake extract exerts hepatoprotective activity in heat-induced oxidative stress in chicken hepatocytes. BMC Complementary and Alternative Medicine, 14 368. DOI: https://doi.org/10.1186/1472-6882-14-368

Pepping J (1999). Milk thistle: Silybum marianum. American Journal of Health System Pharmacy 56(12): 1195-1197. D0I: https://doi.org/10.1093/ajhp/56.12.1195

Pradeep K, Mohan C, Gobianand K, and Karthikeyan S (2007). Silymarin modulates the oxidant-antioxidant imbalance during diethylnitrosamine induced oxidative stress in rats. European journal of Pharmacology, 560(2-3): 110-116. D0I: https://doi.org/10.1016/j.ejphar.2006.12.023

Rajiha AA (2012). The therapeutic effect of Silybum marianum on the lead acetate induced - reproductive toxicity in both gender laboratory rats. Wasit Journal for Science \& Medicine, 5(1): 144-155. https://www.iasj.net/iasj/download/d57fOde9bb5222cb

Rastogi R, Srivastava AK, Srivastava M, and Rastogi AK (2000). Hepatocurative effect of picroliv and silymarin against aflatoxin B1 induced hepatotoxicity in rats. Planta Medica, 66(8): 709-713. DOI: https://doi.org/10.1055/s-2000-9907

Ritz CW, Hulet RM, Self BB, and Denbow DM (1995). Growth and intestinal morphology of male turkeys as influenced by dietary supplementation of amylase and xylanase. Poultry Science, 74(8): 1329-1334. DOI: https://doi.org/10.3382/ps.0741329

Saeed M, Babazadeh D, Arif M, Arain MA, Bhutto ZA, Shar AH, Kakar MU, Manzoor R, and Chao S (2017). Silymarin: a potent hepatoprotective agent in poultry industry. World's Poultry Science Journal 73(3): 483-492. DOI: https://doi.org/10.1017/S0043933917000538

Saller R, Meier R, and Brignoli R (2001). The use of silymarin in the treatment of liver diseases. Drugs, 61(14): 2035-2063. D0I: https://doi.org/10.2165/00003495-200161140-00003

Sakamoto M, Murakami A, Fernandes A, Ospina-Rojas I, Nunes K, and Hirata A (2018). Performance and serum biochemical profile of Japanese quail supplemented with silymarin and contaminated with aflatoxin B1. Poultry Science, 97(1):159-166. D0I: https://doi.org/10.3382/ps/pex277

Schiavone A, Federico R, Quarantelli A, Bruni R, Serventi P, and Fusari A (2007). Use of Silybum marianum fruit extract in broiler chicken nutrition: Influence on performance and meat quality. Journal of Animal Physiology and Animal Nutrition, 91(5-6): 256-262. DOI: https://doi.org/10.1111/j.1439-0396.2007.00701.x

Shahsavan M, Salari S, and Ghorbani M (2021). Effect of dietary inclusion of Silybum marianum oil extraction byproduct on growth performance, immune response and cecal microbial population of broiler chicken. Biotechnology in Animal Husbandry, 37(1): 45-64. Link: https://scindeks-clanci.ceon.rs/data/pdf/1450-9156/2021/1450-91562101045S.pdf

Sonnebichler J, and Zetl I (1986). Biochemical effects of the flavonolignane silibinin on RNA, protein, and DNA synthesis in rat liver. Progress in Clinical and Biological Research, 213: 319-331. https://pubmed.ncbi.nlm.nih.gov/2424029/ 
Soto C, Recoba R, Barron H, Alvarez C, and Favari L (2003). Silymarin increases antioxidant enzymes in alloxan induced diabetes in rat pancreas. Comparative Biochemistry and Physiology Part - C: Toxicology and Pharmacology, 136(3): 205-212. D0I: https://doi.org/10.1016/s1532-0456(03)00214-x

Soto C, Mena R, Luna J, Cerbon M, Larrieta E, Vital P, Uria E, Sanchez M, Recoba R, Barron H, Favari L, and Lara A (2004). Silymarin induces recovery of pancreatic function after alloxan damage in rats. Life Science, 75(18): 2167-2180. DOI: https://doi.org/10.1016/j.lfs.2004.04.019

Suchy P, Strakova E, Kummer V, Herzig I, Písaříková V, Blechová R, and Mašková J (2008). Hepatoprotective effects of milk thistle (Silybum marianum) seed cakes during the chicken broiler fattening. Acta Veterineria Brno, 77(1): 31-38. DOI: https://doi.org/10.2754/avb200877010031

Sultan A, Ahmad S, Khan S, Khan RU, Chand N, Tahir M, and Shakoor A (2018). Comparative Effect of zinc oxide and silymarin on growth, nutrient utilization and hematological parameters of heat distressed broiler. Pakistan Journal of Zoology, 50(2): 751-756. http://researcherslinks.com/current-issues/Comparative-Effect-of-Zinc-Oxide/20/1/1143

Surai $P$ (2015). Silymarin as a natural antioxidant: an overview of the current evidence and perspectives. Antioxidants, 4(1): 204-247. DOI: https://doi.org/10.3390/antiox4010204

Tedesco D, Steidler S, Galletti S, Tameni M, Sonzogni O, and Ravarotto L (2004). Efficacy of silymarin-phospholipid complex in reducing the toxicity of aflatoxin B1 in broiler chicks. Poultry Science, 83(11): 1839-1843. DOI: https://doi.org/10.1093/ps/83.11.1839

Thyagarajan S, Jayaram S, Gopalakrishnan V, Hari R, Jeyakumar P, and Sripathi M (2002). Herbal medicines for liver diseases in India. Journal of Gastroenterology and Hepatology, 17(s3):S370-S6. DOI: https://doi.org/10.1046/i.1440-1746.17.s3.30.x

Tsiouris V, Tassis P, Raj J, Mantzios T, Kiskinis K, Vasiljevi ' c M, Deli ' c N, Petridou E, Brellou GD, Polizopoulou Z, Mittas N, and Georgopoulou I. (2021). Investigation of a novel multicomponent mycotoxin detoxifying agent in amelioration of mycotoxicosis induced by aflatoxinB1 and ochratoxin A in broiler chicks. Toxins, 13(6): 367. DOI: https://doi.org/10.3390/toxins13060367

Upadhyay G, Tiwari MN, Prakash 0, Jyoti A, Shanker R, and Singh MP (2010). Involvement of multiple molecular events in pyrogallolinduced hepatotoxicity and silymarin-mediated protection: evidence from gene expression profiles. Food and Chemical Toxicology, 48: 1660-1670. DOI: https://doi.org/10.1016/j.fct.2010.03.041

Vargas-Mendoza N, Madrigal-Santillan E, Morales-Gonzalez A, Esquivel-Soto J, Esquivel-Chirino C, Gonzalez-Rubio M, Gayosso-de-Lucio J, and Morales-Gonzalez J (2014). Hepatoprotective effect of silymarin. World Journal of Hepatology, 6(3): 144-149. DOI: https://dx.doi.org/10.4254\%2Fwjh.v6.i3.144

Yu Z, Wu F, Tian J, Guo X, and An R (2018). Protective effects of compound ammonium glycyrrhizin, L-arginine, silymarin and glucurolactone against liver damage induced by ochratoxin A in primary chicken hepatocytes. Molecular Medicine Reports, 18(3): 2551-2560. DOI: https://doi.org/10.3892/mmr.2018.9285

Zaker-Esteghamati H, Seidavi AR, and Bouyeh M (2020). A review on the effect of Silybum marianum and its derivatives on broilers under healthy and aflatoxicosis conditions: part 1: Performance, carcass and meat characteristics, and intestinal microflora. World's Poultry Science Journal, 76(2): 318-327. DOI: https://doi.org/10.1080/00439339.2020.1740068

Zarei A, Morovat M, Chamani M, Sadeghi A, and Dadvar P (2016). Effect of in ovo feeding and dietary feeding of Silybum marianum extract on performance, immunity and blood cation-anion balance of broiler chickens exposed to high temperatures. Iranian Journal of Applied Animal Science, 6(3): 697-705. http://ijas.iaurasht.ac.ir/article_524846.html 